\title{
WATCHMEN BY ALAN MOORE AND DAVE GIBBONS: A PRESENTATION OF MORAL DIMENSION IN POPULAR CULTURE
}

This paper examines the presentation of moral dimension in the comic book Watchmen by writer Alan Moore and illustrator Dave Gibbons. It argues that Watchmen engages this issue through juxtaposition of different philosophical views on morality, most notably that of moral consequentialism and moral nonconsequentialism. The varying views are examined in relation to ethical principles of authority, responsibility and moral judgement and the way they inform the individual characters' moral choices, but also in terms of how they inform politics, ideology, and science. Instead of formulating a critique or affirmation of any view, Watchmen perceives them as a means of rationalising the use and/or abuse of power and offers a tentative warning about the dangers of ossification inherent to any value system. This paper aims to show how the refusal to side with any particular view actually indicates that Watchmen purposes for the readers to engage these issues themselves. Furthermore, it aims to affirm the literary and cultural relevancy of the graphic novel as a popular art form.

Key words: popular culture, comic book, Watchmen, moral consequentialism, moral non-consequentialism, authority, responsibility, moral judgement, politics and ideology, science

Comics, especially of the superhero genre, have somewhat of a bad reputation. Much of the reputation is well deserved. The mention of superhero comics usually brings to mind flashily named one-dimensional characters in primary coloured tights running, or flying around saving the world from equally poorly dressed and flashily named villains in an un-

Imejl: astijanaks@yahoo.com

** Deo rada predstavljen na VIII naučnom skupu mladih filologa Srbije u Kragujevcu pod naslovom „Nadzirači Alana Mura i Dejva Gibonsa: Ilustracija konsekvencijalizma i deontologije u popularnoj kulturi““. 
ending series of cringingly repetitive storylines. As Scott McCould, one of rare authors to tackle the comics medium with any degree of seriousness, readily admits, for the most part and for much of their decades long history American comics ${ }^{1}$ were "crude, poorly drawn, semiliterate, cheap, disposable, kiddie fare" (1994: 3). However, McCloud is quick to notice, "the art form - the medium - known as comics is a vessel which can hold any number of ideas and images. The content of those images and ideas is, of course, up to creators" (1994: 6).

Though for quite different reasons, the sentiment was echoed by one Frederic Wertham as early as 1950's. The distinguished psychologist carefully examined the comics of the day and concluded they were harmful to their most avid readers - children. In his book Seduction of the Innocents (1954), as well in his testimony before the Congress, Wertham judged comics to be corrupting minors and inciting juvenile violence through stories and images depicting, among other things, crime, sadism, homoeroticism and gender role reversal. The superhero genre in particular found itself at the receiving end of his criticism:

What is the social meaning of these supermen, superwomen, superlovers, superboys, supergirls, super-ducks, super-mice, supermagicians, super-safe crackers? How did Nietzsche get into the nursery?... Superheroes undermine respect for the law and hardworking decent citizens (Effron, 1996: 13).

Although many of Wertham's views were misguided, he did inadvertently stumble upon a trait that, in a couple of decades, was to serve as the medium's claim to literary and cultural relevance - rather than being a mere kiddy fare, comics have the potential to address social, political, ideological, religious, ethical and a plethora of other issues in a more substantive manner. Unfortunately, Wertham's conservative views garnered a sizeable public support, and the comics industry, in order to win the public approval necessary for its survival, instituted the Comics Code. Strict guidelines the Comics Code established in terms of the content stunted the medium's growth reducing it for years to formulaic, one-dimensional

1 It is necessary to note that, unlike their American counterparts, European and Japanese comics have gained wider acceptance both for their artistic value and as a means of fictional writing for adult audiences. 
WATCHMEN BY ALAN MOORE AND DAVE GIBBONS:

A PRESENTATION OF MORAL DIMENSION IN POPULAR CULTURE

characters whose black and white morality passed the censorship of the public, but was ultimately inconsequential. For the medium to move forward it had to overcome the limitations imposed by the comics industry.

In 1980's, several works appeared that challenged those limitations and in doing so changed both the medium and the perception of it: Frank Miller's Batman: The Dark Knight Returns offered a much darker retelling of Batman in his fifties, forced to deal with both crime and corruption, and the approaching of old age; Art Spiegelman's Maus was a powerful rendition of the horrors of the World War II with the author drawing on the experiences of his family, Holocaust survivors; and Watchmen by Alan Moore and Dave Gibbons, an incredibly well rounded and artistically executed twelve part series published in 1986-1987, later compiled into a single book, dealt with political and moral questions of the contemporary social landscape with never before seen complexity, and in the hindsight, proved to be the most impactful of the lot. It was not only their revisionary character - revisionary in the sense they reinterpreted the characters and gave them depth and gravity that had escaped the medium before, or that they opened the medium to darker, more serious topics such as the Holocaust or political and social issues - but that they both revisited the history of the medium and offered a successful introspective examination of the human condition. Nietzsche had not so much wandered into the nursery, as the medium had finally grown out of its painfully long adolescence and moved towards artistic and thematic adulthood.

\section{Watchmen}

Watchmen, penned by Alan Moore and illustrated by David Gibbons, is a superhero comic book ${ }^{2}$. It was the result of Alan Moore's desire to tackle the superhero genre. After the successful cooperation with DC

$2 \quad$ Although the term "graphic novel" is frequently used, especially to distinguish more "serious" or artistically accomplished comic books from those perceived as "light" entertainment, Alan Moore himself has on more than once occasion spoken against the use of the term, describing it as nothing more than a marketing gimmick used by the comics industry to achieve higher sales. Though the use of either term has its merits and demerits, for the sake of consistency, this paper will refer to Watchmen as a comic book. 
Comics on the Swamp Thing series, Moore had hoped to use and develop characters from another company's comic book universe that DC had previously purchased for his own take on the superheroes. However, DC felt reluctant to entrust the characters to Moore's admittedly much darker vision, so instead of the characters he had hoped to use Moore was now free to create his own. The creative freedom enabled him to handle the genre and the characters as daringly as he pleased - the freedom Moore used to problematize both the narrative and the ethical principles that had thus far shaped the superhero genre. In Superheroes: A Modern Mythology, Richard Reynolds defines superhero comics as "a popular art-form traditionally known for its apparently hegemonic and sometimes overtly authoritarian texts" (1992: 7). Usually, a superhero is the generic "good guy" - a morally upright individual who uses his/her powers to protect the public. Even if the moral fibre of the protagonists is tested, even if they occasionally falter, those instances are merely exceptions that affirm their otherwise upright character. Despite their exceptional abilities superheroes also seem less interested in engaging the world by questioning the existing political, social or moral structures or working towards a change, but are dedicated to perpetuating the ruling ideology and maintaining status quo. Moore, however, stripped his narrative and his characters of any such simplistic solutions.

The characters Moore created in the image of the clean-cut, invulnerable super-powered hero of justice the genre had become synonymous with, had less to do with this idealized reflection of humanity and everything with its vulnerability, irrationality and imperfections. In the introduction to the Watchmen Graphitti edition, Moore stated that while working on the series he had reached a point where he was able to "purge" himself of the nostalgia for the super-hero characters and bring his interest in real human beings to the forefront. He felt he could not explain certain circumstances of his character's lives without considering their political opinions, sexuality, philosophy and other factors of the world which shaped them into who they are, and similarly, he could not create their world without referencing and rethinking our own. His characters, though undoubtedly drawing on a traditional hero type, are nonetheless independent, fully formed, with surprisingly complex psychological profiles and a "disturbing morality" (Watchmen, 2006: 415). In fact, only one of them has any actual superhuman abilities, the rest are merely men and women in costumes, painfully human, gratingly flawed and most of the time riding the moral 
WATCHMEN BY ALAN MOORE AND DAVE GIBBONS:

A PRESENTATION OF MORAL DIMENSION IN POPULAR CULTURE

fence. As Ian Thompson notices, in Watchmen "the hero is destroyed by the superhero, who is more heroic than any hero, but whose extreme 'heroics`are no longer recognisable as heroics" (2005: 106). By immersing the world of Watchmen in the complexities of the contemporary social landscape and stripping its protagonists of the naive, meticulously fenced-in black and white morality, Moore had had "something more going on than just a darker take on the super hero" (Toasting, 2000b). In Moore's own words, he "produced a moral and political fable that used icons of superhero adventure fiction to make its point" (DiLiddo, 2009: 55).

Watchmen starts out as a murder mystery. The dead hero is Edward Blake, a masked crime fighter employed by the government under the alias the Comedian, who meets his doom after being thrown from a window of his New York apartment. In an interview, Moore said it was "a good way to start a comic book: have a famous super-hero found dead. As the mystery unravelled, we would be lead deeper and deeper into the real heart of this super-hero's world, and show a reality that was very different to the general public image of the super-hero" (Toasting, 2000b).

Blake's murder is incidentally investigated by Rorschach, real name Walter Kovacs, a rogue vigilante who comes to the conclusion that someone is targeting masked adventurers. Rorschach then visits his former masked associates in order to relay his suspicions and warn them of the impending danger. He meets Dan Dreiberg a.k.a Nite Owl, a wealthy ornithologist; Adrian Veidt, also known as Ozymandias, a self-made billionaire; John Osterman, better known as Dr. Manhattan, a scientist and the only character with super-powers having obtained them after an accident in a nuclear research facility, as well as his girlfriend, Laurie Juspeczyk, a former masked adventurer herself called Silk Spectre. These characters, we learn, are the second generation of masked crime-fighters. The history of "masks" began in 1938 with the appearance of the first cloaked hero, Hooded Justice and the original Nite Owl, Hollis Mason. This original group of masked heroes, the Minutemen, also included the Comedian, and Sally Jupiter, mother of the current Silk Spectre. In an interesting twist, most masked adventures are now retired due to public outcry which led the government to adopt an act outlawing their activities with the exception of those who, like the Comedian or Dr Manhattan, continue to work directly for the government, and except Rorschach who refused to retire and went underground. 
At first, no one pays much attention to Rorschach's suspicions, with many of the protagonist describing him as somewhat unbalanced if not psychotic; however, little by little his predictions come to fruition. After being accused of having caused cancer in his former co-workers, Dr Manhattan exiles himself to Mars. Since Dr Manhattan's remarkable abilities served as a deterrent in the Cold War between the USA and Russia, his absence leads to escalation of hostilities. An attempt is made on Adrian Veidt's life, while Rorschach himself is set up for murder of an old adversary and imprisoned. With the help of Laurie, Dan Dreiberg breaks out Rorschach from prison, and the two of them trace the leads surrounding the attacks on the "masks" to Adrian Veidt. Another more sinister plot by Veidt is soon revealed.

Often described as the smartest man in the world, Veidt sees political situation in the world escalating towards nuclear annihilation and in order to prevent it, decides to frighten the planet into peace by exploding a genetically engineered "alien" being in the middle of New York, killing millions. The unknown extra-terrestrial being would then unite the planet against the perceived common threat. By the time others reach Veidt in his Antarctica home, he had already executed his plan. Everyone agrees to keep silent on his actions in order to preserve the peace achieved at the cost of so many lives, except Rorschach who is then disintegrated by Dr Manhattan. However, before heading out to Antarctica, Rorschach had mailed his diary, detailing the affair and naming Veidt the culprit, to a daily newspaper and the story ends with his diary about to be picked up and read by an assistant editor.

This simple retelling of the plot, however, does not account for the complexity of the work itself. Watchmen thrives on the possibilities offered by the happy marriage of words and images: "pictures... belie words. They provide contexts for words. They also provide subtexts, thereby complicating verbal messages... Words, conversely... shape the way we look at pictures" (Warnum, Gibbons, 2001: xiv). Moore includes numerous prose insertions at the end of chapters, excerpts from autobiographies, diaries, interviews, police reports, psychiatric evaluations etc., and a multitude of intertextual references - allusions to and quotations from other superhero comics, literature (Blake, Shelly), philosophy and religion (Nietzsche, the Bible), popular music (Elvis Costello, Bob Dylan), even a story-withinthe-story, a pirate narrative, as a counterpoint to the overall narrative creating multiple layers of meaning never before seen in comics, let alone of the superhero genre. As Moore himself said "with Watchmen, what [he] 
WATCHMEN BY ALAN MOORE AND DAVE GIBBONS:

A PRESENTATION OF MORAL DIMENSION IN POPULAR CULTURE

tried to do was give it a truly kind of crystalline structure, where it's like this kind of jewel with hundreds and hundreds of facets and almost each of the facets is commenting on all of the other facets and you can kind of look at the jewel through any of the facets and still get a coherent reading" (Blather, 2000a). This is one of the reasons Watchmen is hailed as the first "postmodern comic book" (Thompson, 2005: 102) in that it employs a variety of structural and narrative techniques and strategies that both sustain and subvert the mass cultural process that produced it. As Carney aptly notices, Watchmen is "emblematic of the artistic strategies which Jameson envisions for postmodern art, which can respond to the cultural logic of late capitalism not by rejecting its symptoms, but by embracing them and using them against that cultural logic" (2006: para 21).

Moore's premise was of superheroes placed in "real" word and how the world would be affected through the interaction. The America of Moore's creation is a dystopian society, though eerily recognisable as our own, plagued by the same social and political turbulences of the "real" world: clash of ideologies, pervasive nuclear armaments race, street crime, sexual relations. Moore achieved this uncanny resemblance by intermingling actual historical events with those of the alternate history: Cold War, the assassination of Kennedy, the death of Kitty Genovese, all occur in a world where superheroes are everyday occurrence, electrical cars navigate the streets of America that had won the Vietnam war, and where Nixon is still the president having changed the Constitution to allow his re-election. However, it should be noted that the "apparent postmodern pyrotechnics" (Narcisi, 2013: 3) do not take away from what Watchmen truly is - "a meditation about power" (Flynn, 2012: 11) and more importantly, about its ethical implications.

\section{Superheroes and questions of morality}

In his programmatic essay "On Writing Comics", Moore suggested that his choice of an ideal narrative structure would be "the basic elliptical structure, where elements at the beginning of the story mirror events which are to happen at the end, or where a particular phrase or a particular image will be used at the beginning and at the end, acting as bookends to give the story that takes place in between a sense of neatness and unity" (Writing, 2003: 15). The particular phrase in Watchmen is a quote by Juvenal, "Quis custodiet ipsos custodies". 
"Who is to keep guard over the guards themselves?" - the question posed by the Roman poet in Book IV of his Satires to Roman patricians who hired guards to stand watch over their wives' chastity noting that the very people hired to guard could become those that needed guarding against. The same quote was used as the epigraph of the 1987 Tower Commission Report which dealt with the possible abuses and overreach of the USA government in the Iran-Contra scandal. For Moore, the phrase "who watches the watchmen" did not merely provide the title of his comic book, but also became "the central critical perspective of the work" (Di Liddo, 2009: 55).

Juvenal's question highlights closely related ethical principles - that of authority, responsibility and ethical judgement - inherent to the use of power. Moral judgement assumes the existence of standards, of moral conventions or moral convictions; therefore the first implication always has to do with them: what are the standards by which moral judgements themselves are to be judged by? The next refers to the "who": who judges and who do they judge? Such questions imply a rationale, a virtue of reasoning about the matters of right or wrong, yet "people can [reasonably] conceive of welfare-increasing wrongs, welfare-decreasing rights, wrongful obedience, and rightful disobedience" (DeScioli, Kurzban, 2009: 283). Therefore, the role of emotions in forming moral judgements, also of emotions that arise in response to moral judgements, should also be examined as their integral part. By virtue of creating characters with such complex psychological profiles, Moore gives us an insight into the moral psychology of his protagonists, or rather how the twin components of moral cognition - conscience, which guides our actions, and condemnation, which guides us to seek punishment for moral transgressions, as well as moral emotions, both the self-conscious (shame, embarrassment, guilt) and other-critical ones (contempt, anger, disgust) - inform our moral choices. Watchmen depicts the world as morally textured and differentiated, and it is no wonder that the actions and reactions of Moore's characters to moral quandaries that such world inevitably invites are just as varied and conflicting. In this sense, Watchmen is a decisive break from the tradition of superhero comics preceding it.

Comic book heroes - superheroes - are above all else moral heroes. Accordingly, the most devastating weapon at their disposal is not their superpowers, but rather, the "moral high ground" (DeScioli, Kurzban, 2008: 245). Because they act from the position of the moral high ground they embody the blindfolded Justice; we can trust their judgement to be fair 
WATCHMEN BY ALAN MOORE AND DAVE GIBBONS:

A PRESENTATION OF MORAL DIMENSION IN POPULAR CULTURE

and impartial and the punishment of those who commit transgressions in proportion to the severity of the crime, so that everyone gets their just deserts. Superheroes are therefore exemplars, designed to serve as moral role models. Ian Thomson notices how "our identities as individuals and as groups are shaped, in ways both subtle and profound, by our heroes. If our enemies... help give us a sense of who we are not, of what we stand against, then, conversely, our heroes help tell us who we are, what we stand for... The heroes we choose... shape our feel for which battles we should fight as well as how we should go about fighting them" (2005: 100). A comic book superhero, then, is the perfect distillation of that aspiration, an idealized, hyperbolic reflection of humanity, and therefore, an entirely impossible existence. However, Watchmen pointedly steers away from such an idealised superhero. There is not a single masked adventurer in Watchmen that can honestly be described as simply a "hero" or a "villain". The protagonists do have their own convictions and some are certainly prepared to go extreme distances when acting on them, but rather than just having the individual characters stand for a particular ethical view, Moore is more interested in the process of how such convictions were formed and how they morphed over time and what their outcomes are. For Moore, the "origins story" often used in comics to explain how the superheroes came to be or how they obtained their powers, is a device to problematize the moral process not only of his characters but of the various aspects of society. Most importantly, Watchmen not only presents the world as morally textured and differentiated, but marks a decisive break from its predecessors by refusing to side with a "right" type of morality, and leaves it at the discretion of readers to reach their own conclusions.

\section{Watchmen's (anti)heroes}

The first look into the questions of morality is provided by Hollis Mason, the first Nite Owl. A country boy who moved to New York at the age of 12 when his father relocated the family from the country to the city, Mason admits to having "a certain set of moral values and moral conditions" stamped upon him by his grandfather, or what he calls "a basic sense of decency" (Watchmen, I, 4). It is the type of morality he most easily recognised in pulp adventure fiction, the world of Doc Savage and the 
Shadow, a world of "absolute values, where what was good was never in the slightest doubt and where what was evil inevitably suffered some fitting punishment... a perfect world where morality worked the way it was meant to" (Watchmen, I, 5). However, this perfect world only made the ugliness of the real one - inhabited by pimps, pornographers, con artists, child molesters, and teenage criminals - harsher by comparison. Mason claims he felt sick to his gut at world and what was becoming of it, and this "ethical revulsion" was the reason that first led him to become a policeman, and Nite Owl afterwards. Essentially, his masked alter ego is an extension of his desire to enforce law, "We were doing something because we believed in it. We were attempting, through our personal efforts, to make our country a safer and better place to live in" (Watchmen, II, 8). Mason possibly comes closest to the tradition of the comic book heroes preceding Watchmen, of the generic "good guy", however he also marks the departure from it. Mason recounts the story of an event from his childhood, the suicide of Moe Vernon, the owner of the car repair shop his father had worked for and it is the dark overtones of this story that first indicate Watchmen's break with the tradition of the morally good vs. morally bad binary that comics typically relied on.

Moe Vernon, the middle aged owner of an auto repair shop is described as a simple, good natured man, the salt-of-the-earth type, his rather child-like innocence and pure heart revealed through his hobby of collecting funny and sometimes racy toys and gadgets from gag shops to play pranks on his workers. Then one day Moe discovers that not only had his wife been cheating on him with his most senior and most trusted mechanic, Fred Motz, but that she had taken all his money and escaped with her lover to Mexico. Shocked by the revelation, Moe reveals the fact to everyone in the shop. However, because he is shocked and distraught, Moe forgets to take off a pair of fake breasts he is wearing as a practical joke and his grotesque appearance causes everyone to burst out laughing. The story makes for an uncomfortable reading. Moe Vernon may well be called a victim; he was undoubtedly wronged by his wife but there is a striking absence of moral judgement on the part of the workers. Furthermore, the story presents an example of human misfortune inviting ridicule rather than compassion. We witness a failure of that basic sense of decency that Mason advocates and which is his guiding principle. More importantly, these are not "bad" people, bad in the sense that they are intentionally hurtful to Moe, and they most certainly mean him no harm - their reaction is inappropriate and illadvised but not enough to tip it to the wrong side of the moral fence. The irony 
WATCHMEN BY ALAN MOORE AND DAVE GIBBONS:

A PRESENTATION OF MORAL DIMENSION IN POPULAR CULTURE

of it is even more accentuated when Fred Motz is reemployed by the new owner of the shop after Moe's suicide. Fred Motz cannot be held responsible for Moe's suicide any more than the workers who burst out laughing at his predicament, but to see him back at the shop does strike a sharper key on the moral scale. Hollis Mason calls this story the saddest one ever, but placing it at the very first chapter sounds a warning - there are no absolute values, no black and white morality since even "good" people are capable of committing "bad" things. Watchmen not only depicts the world as morally ambiguous, but initiates the discussion on how actions should be judged, by their outcomes or by their nature, juxtaposing consequentialist and non-consequentialist views on morality.

As Mason continues to talk about other fellow Minutemen, it becomes clear that few of them actually share his moral stance. Captain Metropolis, a former Marine, at first seems to fit the same mould as Hollis Mason. However, the issues he chooses to act against are morally ambiguous: "promiscuity", "anti-war demonstrations" and "black unrest". The Comedian transitions from a young crime fighter to "an ethically confused government weapon that has a skewered perception of good and evil [and this] dismantled view of good and bad is seen in his gleeful appreciation of carnage during riots in New York City, the rape of Laurie's mother, and the murder of his Vietnamese mistress" (Rapp, 2012: 11). The first Silk Spectre becomes a crime fighter as a publicity stunt to advance her modelling career; Hooded Justice is described as espousing the Third Reich, while Mothman seems to have left-wing affiliations, and it is insinuated their political convictions might have influenced their decision to become crime fighters. First-generation masked heroes are flawed, contradictory, and controversial, the fact even more thoroughly explored with the second generation.

The Comedian connects the two generations since his career spans several decades. As a 16-year old kid, he embarks on a career of crime fighting cleaning up New York docs from criminals, but later becomes a government operative. He is depicted as crude and violent, abusing his services to the country for self-gratifying ends that are for the most part in themselves also crude and violent. He is Watchmen's arguably most easily disliked character and represents not only a break from the comics tradition but a stinging satirical reworking of the state-sponsored, all-American morally righteous hero that had previously donned the pages of comics. Dr 
Manhattan calls him "deliberately amoral". As he comments on the Comedian's actions in Vietnam, Dr Manhattan notices:

He suits the climate here: the madness, the pointless butchery... As I come to understand Vietnam and what it implies about the human condition, I also realise that few humans will permit themselves such an understanding. Blake's different. He understands perfectly... and he doesn't care (Watchmen, IV, 19).

The Comedian has seen the worst of humanity and has come to expect the worst of it. "What's going on down in this world, you got no idea. Believe me" (Watchmen, II, 10), he says to the crime fighters gathered at the meeting organised by Captain Metropolis. He is perfectly aware that the world will spiral out of control, and head towards a nuclear conflict, years before it actually does. His various experiences provide him with a deeper insight, but that knowledge makes him "ruthless, cynical, and nihilistic" (Reynolds, 1992: 160), to the point that he is able to murder his pregnant lover. When Dr Manhattan reprimands him for gunning down his Vietnamese lover, the Comedian immediately points out that he could have stopped him, but did not. The Comedian understands the concepts of right and wrong, but sees both as arbitrary and easily abused. He sees the American dream distorted and does not allow himself the luxury of closing his eyes to the fact. The Comedian is not a hypocrite since he does not pretend to be acting on some higher moral purpose, and he also refuses to acknowledge others who pretend to be doing do. Rorschach would observe that the Comedian "saw the true face of the twentieth century and chose to become a reflection of it, a parody" (Watchmen, II, 27). His "deliberate amorality" may as well be defined as excessive moral flexibility, this lack of anchoring enabling him to drift across moral landscape from one extreme to another, allowing him to both murder his unborn child and show affection for his daughter Laurie. Ultimately, the Comedian fails to formulate any kind of ethical response to the world around him, his lack of moral anchoring making him self-contained and isolated. It is also the cause of his hesitation when he accidentally discovers Veidt's plan. For a man of action, his immediate response to this moral dilemma is inaction, and it proves to be his undoing. The Comedian's demise seems to demonstrate that avoiding responsibility does not equate with having none. However, 
WATCHMEN BY ALAN MOORE AND DAVE GIBBONS:

A PRESENTATION OF MORAL DIMENSION IN POPULAR CULTURE

rather than arguing the necessity of a well-defined moral stance, Watchmen instead questions if not having one may be just as problematic.

Finding one's way in the ethical maze becomes the central problem for the character of Dr Manhattan as well. As mentioned earlier, he is the only character in the Watchmen universe to have actual super-powers, but unlike the typical comic book superhero who is a benevolent force, existing and acting for the good of all mankind, Moore subverts this tradition by turning Dr Manhattan into more of a threat to mankind than its saviour. Born Jon Osterman, Dr Manhattan is the son of a simple watchmaker, and aspires to become one as well. However, after witnessing the devastating power of the atomic bombs dropped in Japan, his father realises that in this new world watchmakers will have become obsolete, an anachronism, and pushes his son into becoming a physicist. Osterman does eventually become a scientist and joins a team at a nuclear research facility. Due to an unintentional oversight, he is disintegrated in a chamber for intrinsic field experiments, but is somehow able to reassemble an approximation of his physical body, and in the process obtain "a complete mastery of all mater [through which he is able to] shape the reality by the manipulation of its basic building blocks." (Watchmen, IV, II). Not only does he become superior in terms of his intelligence and matter manipulation, but he no longer ages, does not feel warm or cold, and his perception of time changes - rather than linear it becomes simultaneous; he experiences past, future and present at the same time. Jon's humanity, however, is compromised by his newly acquired abilities and he seems to be shedding more and more of his human self as the narrative progresses, just as he keeps shedding more and more of his clothes and in the final panels of the comic books is completely naked signalling both retreat from the humanity and emotional detachment from its, as well as from human values that would render his nakedness socially inappropriate.

When he first joins the research facility, Jon explains the reason he became a scientist: "Well, you know... my dad sort of pushed me into it. That happens to me a lot. Other people seem to make my moves for me" (Watchmen, IV, 5). He submits to the authority without questioning it, first of his father, and after the accident, to that of the state. As soon as they realise the extent of his extraordinary abilities, the American government reveal his existence renaming him Dr. Manhattan due to the "ominous associations it will raise in America's enemies", shaping him into "something gaudy and lethal" (Watchmen, IV, 12). These actions seem to un- 
dercut both his identity as Jon Osterman and his moral volition. The press says he is a crime fighter, so he fights crime; the government sends him to Vietnam, so he fights their war; when the need arises, he suppresses riots in Washington. It is somehow implicitly understood that Dr. Manhattan's powers do not belong to him but to everyone, or rather everyone else; it is implicitly expected that he accepts and employs his powers in certain manner, ostensibly for the betterment of mankind; however, he is consistently denied the opportunity to formulate his own opinion. Eventually, his blind obedience to the authority drives him into a moral dead-end. "The morality of my activities escapes me" (Watchmen, IV, 12), says Dr Manhattan noting at the same time how "it's all getting out of my hands" (Watchmen, II, 14). Just as refused to use the image of an atom as his symbol opting for hydrogen instead, Dr. Manhattan sets out to chart his own way in the ethical maze and formulate his own moral stance. In doing so, Watchmen raise several important questions, the first one focusing on the notion of individual responsibility, the second one contrasting sharply the needs of the many and the rights of an individual.

Christopher Robichaud reasons that Dr Manhattan's "supreme intelligence and power - his godlike standing - do not exempt him from being held to the same moral standards that the rest of us are held to" (White, 2009: 11), since no one is, or should be above the moral law. Arguably, no one on the planet could be able to force any moral obligations upon Dr Manhattan should he choose not to follow them. This immediately invites another question - what are the grounds of morality, what gives the moral principles their force over us, and how such moral obligations can be enforced on someone if the possibility of enforcement or punishment is taken from our hands, for one reason or another? Do we follow moral conventions because our conscience tells us to or because we are afraid of condemnation? It is these questions of authority and responsibility that Dr Manhattan grapples with. It is not that the concepts of right and wrong elude him; his moral quandary is not how he should apply his extraordinary powers, but rather if he should apply them at all. He is aware that his very existence has unbalanced the world, and when it is suggested that he might have caused cancer in his once co-workers, Dr Manhattan exiles himself to Mars. He fully understands the seriousness and the gravity of the political situation in the world, but chooses not to get involved any further. "All those generations of struggle, what purpose did they ever achieve? All that effort, and what did it ever lead to?" (Watchmen, IX, 10), Dr Manhattan asks, "Which of us 
WATCHMEN BY ALAN MOORE AND DAVE GIBBONS:

A PRESENTATION OF MORAL DIMENSION IN POPULAR CULTURE

is responsible? Who makes the world?" (Watchmen, IV, 27). Even if our actions are rendered futile by the certainty of an outcome, should we forego all action knowing it is meaningless or act nonetheless? For Dr Manhattan this ethical dilemma translates into a quest for finding the meaning of human existence does human life, and the very existence of mankind, have any inherent ethical value? "We gaze continually at the world and it grows dull in our perceptions. Yet seen from another's vantage point, as it new, it may still take the breath away" (Watchmen, IX, 27). For Dr Manhattan each individual human life is therefore "a thermodynamic miracle", a unique and unrepeatable occurrence. His regained interest in humanity is not based on the outcome, the individual human being, but rather on the process, both the process of the creation of human life and its aftermath. The continuity of the process, the fact that "nothing ever ends" (Watchmen, XII, 27), informs his ethical position and he neither condones nor condemns Veidt's actions acknowledging they are a point in an ongoing process. If the Comedian suffers from excessive moral flexibility, Dr Manhattan's blend of morality is a fluid one - on one hand it questions the blind acceptance of moral authority, and on the other constantly revaluates his own role in forming moral convictions.

Whereas Dr Manhattan's responses to ethical dilemmas are cerebral, Rorschach's are decidedly emotional - he may well be the most tortured and troubling character of the entire superhero genre. His appearance is reminiscent of the typical trench coat and fedora wearing detectives, but all similarities end at that point. He is dark and obsessive in a way more becoming the villains of the genre than its heroes and is Watchmen's most ambivalent character. Sean Carney describes Rorschach as "mentally deranged, amorally violent, sexually repressed, and alienated from humanity; his motives for fighting crime are revealed to be the product of both childhood trauma and a gradual loss of belief in the worthiness of human race" (2006: para 18). Walter Kovacs has indeed seen much of the ugliness of the world since his childhood. Born to a prostitute mother and never having known his father, he is frequently neglected and abused by her and often bullied by other kids. He also spends a number of years under the care of an institution for problem children whose records describe him as a serious, but shy child with impressive skills as a gymnast and amateur boxer. While working a menial job in a garments factory, he comes across a special order dress made from two layers of latex filled in between with black, heat and pressure sensitive fluid. The woman, who turns out to have been Kitty Genovese, never collected the 
dress because she thought it ugly. The horrid circumstances of Kitty Genovese's death - she was raped, tortured and killed in front of her own apartment building while none of the neighbours called the police even as she screamed for help in plain sight of all - prompt Walter Kovacs to become a masked vigilante. "I knew what people were then" says Rorschach, "Behind all the evasions, all the self-deception. Ashamed for humanity, I went home. I took the remains of her unwanted dress, and made a face that I could bear to look at in the mirror" (Watchmen, VI, 10).

Hollis Mason talks about "moral aversion" as the reason he became a masked vigilante, but at the same time he admits the "he fought crime because it was fun and because it needed doing, and because [he] goddamn felt like it" (Watchmen, I, 5). Rorschach is evidently a darker, more unsavoury rendering of a masked crime fighter. As Brent Fishbaugh notices, he "joins the fad of costumed crime fighting not for fun, but out of guilt - guilt over what his entire race has become, guilt spawned not just from the events [that] surround Kitty Genovese's death, but from his own misbegotten upbringing" (1998: 193). Carney also claims that "Rorschach is a vigilante because he hates humanity and sees it as a cesspool of filth not because he loves it" (2006: para 18). Rorschach most certainly is no stranger to the city's dark underbelly. He describes it as dying from rabies, which in itself is a poignant image - not cancer that slowly eats away at it, but the violent, contagious disease with no cure, leading to painful death, a disease signalling the retreat of reason and rationality before blind frenzy and animality. Rorschach observes this downward spiral as not limited to New York alone, but rather as the condition of mankind at large: "Soon there will be war. Millions will burn. Millions will perish in sickness and misery... if and when we go to hell... we have only ourselves to blame" (Watchmen, I, 24). It is not guilt, but rather contempt, anger, and disgust that Rorschach feels at humanity and by association at himself. He does not see himself as somehow removed or different from the rest humanity, but rather, he acutely feels he $i s$ a part of it. Rorschach is similar to the Comedian in that he refuses to be a hypocrite, refuses to close his eyes to mankind's capacity for evil. When Rorschach contests his doctor's perception of himself as "a good person", he does so by exposing the doctor's self-serving motives for treating him. There are others whose behaviour is even more extreme than Rorschach's, however, they are unknown individuals who cannot provide the doctor with the public exposure and recognition he craves. "You don't want to make me well", concludes 
WATCHMEN BY ALAN MOORE AND DAVE GIBBONS:

A PRESENTATION OF MORAL DIMENSION IN POPULAR CULTURE

Rorschach, "[you] just want to know what makes me sick" (Watchmen, VI, 11). Reacting to misfortune of others with laughter instead of compassion, failing to help a person in danger, those acts of indifference and acts of omission blur our perception of right and wrong, open too many "grey" areas for mankind to get lost in, and extend the boundaries of what is morally permissible. Rather than representing a call for absolute moral values, Rorschach's constantly changing mask may instead be a call for clarity, the kind of clarity that reveals moral hypocrisy in "good people" when they fail to act, as much as it reveals the presence of evil.

Rorschach's mask lends itself to many interpretations. The constantly shifting black blots have no inherent meaning, yet much like in the inkblot test, the chaotic contours are perceived as aligned in a certain manner and a meaning is ascribed to them. The mask therefore is a reflection: of Rorschach himself, of the world he inhabits, of other characters in the Watchmen universe. More importantly, the mask is a less than subtle invitation to readers themselves to determine their stance on the ethical questions posed both by Rorschach and Watchmen as a whole. This mirroring function of the mask is one of its important aspects in ethical terms - a mirror "not only reflects; it transforms, it becomes a crucible" (Suvin, 1979: 5). Rorschach transforms himself, but the cost of the transformation is a gradual loss of identity, and gradual alienation from humanity. It causes an almost schizoid split between his real self and his alter ego, to the point where Rorschach becomes not only his real identity but his only identity, and Walter Kovacs - a mask Rorschach wears. It is most clearly seen in Rorschach's language - the monotone, emotionless voice, broken syntax, the pointed absence of pronouns, especially the absence of "I". Whereas Dr Manhattan's departure from humanity is not a willing act but the result of extraordinary circumstances, Rorschach does so by choice. As Rorschach himself states in what may well be the clearest expression of his ethical stance:

Once a man has seen he can never turn his back on it. Never pretend it doesn't exist. No matter who orders him to look the other way. We do not do this thing because it is permitted. We do it because we have to. We do it because we are compelled (Watchmen, VI, 15).

If the death of Kitty Genovese is a catalyst of the change; the death of Blaire Roche becomes an epiphanal experience. A six-year old child is kidnapped, mistaken for a relative of a wealthy family. While searching 
the culprit's home, Rorschach finds evidence of the girl's presence but not the girl herself until he looks into the yard and sees two German shepherds playing with human bones. Rather than admitting to his mistake, the kidnapper killed the girl, cut up her body and fed her remains to his dogs. The incident gives Rorschach "a certain kind of insight" and this insight clearly delineates individual responsibility as central to our moral action:

Existence is random. Has no pattern save what we imagine after staring at it for too long. No meaning save what we choose to impose. This rudderless world is not shaped by vague metaphysical forces. It is not god who kills children. Not fate that butchers them or destiny that feeds them to the dogs. It's us. Only us.

(Watchmen, VI, 26)

The existence of Rorschach overwrites that of Walter Kovacs and along with it his ethical position is reformulated; Rorschach no longer weighs the world on moral scales and against a moral standard provided by the prevailing ideology or a religion or any other system, but rather, takes the measure of the world and creates his own set of values. He describes himself as being reborn and "free to scrawl own design on the morally blank world" (Watchmen, VI, 26). "There is good and there is evil, and evil must be punished", explains Rorschach in what must be the clearest expression moral non-consequentialism in Watchmen, "Even in the face of Armageddon I shall not compromise in this" (Watchmen, I, 24).

This is the reason Jacob Held believes Rorschach to be the embodiment of the "retributive theory of punishment" (White, 2009: 20) - evil must be punished not because doing so makes the world a better place, but simply because it is evil and therefore deserving of punishment. Held recognises three distinctive components of retributivism, which he also associates with Rorschach: only the guilty are to be punished, the punishment must be proportionate to the severity of the crime, and the punishment, seeing it returns the suffering for the wrongdoing, is in itself morally good. Punishment therefore has less to do with paying the harm back, and is more with "balancing the scales, restoring order, and affirming fundamental values" (2009: 29). While Rorschach does say that there are many deserving of retribution, his blend of non-consequentialism is too conflicting and too extreme to accommodate this view. On hand he is able to 
WATCHMEN BY ALAN MOORE AND DAVE GIBBONS:

A PRESENTATION OF MORAL DIMENSION IN POPULAR CULTURE

overlook "moral lapses" of the Comedian (for instance, the rape of the first Silk Spectre), and on the other he is able to terrorise, threaten and injure innocent people during his investigations which makes him blind to his own moral ambiguities. Rorschach acknowledges that his actions might have little effect towards levelling of the scales and restoration of order. The city is dying of rabies, and he can do little else except "wipe random flecks of foam from its lips" (Watchmen, I, 16). However, once he has seen the darkness at the heart of mankind, he cannot look away. Rorschach is no longer naïve and soft, he no longer "mollycoddles" the guilty. He sacrifices compassion and empathy to turn himself into an instrument of punishment, and since punishment can only be called moral when impartial, he foregoes all loyalty and caring, seeing that "one cannot be both a good altruist and an impartial moralist" (DeScioli, Kurzban 2009: 295). However, in the process, he has willingly sacrificed his humanity, turned himself into a monster in order to battle monsters, and in doing so has lost the sight not just of the value of humanity but of his own value as human beings. This is perhaps what makes Rorschach's character so tragic, especially in contrast to the self-serving ends of Adrian Veidt..

Chapter V of Watchmen, "Fearful Symmetry", is usually considered as one of the Rorschach chapters since it deals with his pursuit and capture. Then there is the obvious reference to William Blake's poem "The Tyger" which lends the chapter its name. Blake's noted poem juxtaposes the image of the fierce and destructive tiger with that of a peaceful, gentle lamb, and questions the design of the Creator. The poem examines the presence of evil in the world; however, the extraordinary nature of the tiger - despite its destructive nature, the tiger is nonetheless awe-inspiring and beautiful - complicates the binary opposition of good and evil showing both good and evil existing within one form. Rorschach may represent the blakean tiger the implication being that, while his actions, as radical and brutal as they are, may seem "evil", there is still "good" in him in the sense that his pursuit of justice is morally good, even if his methods are questionable. As Jamie Hughes notices, "for every man Rorschach has killed, he has also rescued a child or stopped a drug dealer, so while some view him as a half-crazed man who cares little for society, the reverse can also be true" (2006: 552). This chapter however also reveals another fearful symmetry - that of Rorschach and Ozymandias.

Of all characters in Watchmen Adrian Veidt a.k.a. Ozymandias fills the shoes of a superhero most comfortably. He seems to embody the en- 
terprise and ingenuity that built the civilisation, all that is best and most praiseworthy about mankind. Though raised in a wealthy family, Veidt gives away his fortune to show that nothing is impossible if a man applies himself. He becomes one of America's best-respected superheroes, the job he then quits to pursue a career in business through which he amasses enormous wealth. Veidt's public image of is completely opposite to that of Rorschach. Whereas Rorschach is perceived as a deranged sociopath with murderous tendencies, Veidt is a model individual - the world's smartest man, successful, altruistic, open-minded, and physically attractive, one whom even Rorschach describes as "a better class of person" (Watchmen, I, 16). Yet, just as the tiger's perfectly beautiful, awe-inspiring exterior hides his deeply destructive nature, Veidt's benevolent image masks more sinister intentions.

Beyond any doubt Veidt is an exceptional individual, however, his "exceptional intellect invests him with a sense of destiny, but without providing a specific goal" (White, 2009: 57). When a purpose eventually presents itself to Veidt, it is, no more and no less, the salvation of the world. Ethical implications of such an objective are man, the foremost being on what grounds does Veidt believe himself entitled to decide the faith of the world? Does any one person, however extraordinary, have the right to be the judge of all Earth?

Talking about nuclear weapons and the culture of fear they breed, in a 1987 documentary, Moore argues that a whole generation is raised "who cannot see past the final exclamation mark of a mushroom cloud. They are a generation who can see no moral values that do not end in a crackling crater somewhere". He also notices how it is "very, very naive to assume that you can expose the entire population of the world to the threat of being turned to cinders without them starting to act, perhaps, a little oddly" (Narcisi, 2013, 5-6). In a way, Veidt is the product of the nuclear age in much more literal way than Dr Manhattan. Veidt too understands that darkness in the human heart will eventually be its downfall, but unlike Rorschach, who chooses to reflect it back to the world as a tool of moralistic punishment, Veidt wishes to eradicate it. As Carney states, Veidt sees himself as "honestly benevolent in his thinking: he takes an enormous burden of guilt upon himself and he is willing to do anything to guarantee the survival of humanity" (Carney, 2006: para18). His ultimate goal, in his own words, is "to usher in an age of illumination so dazzling that humanity will reject the darkness in its heart" (Watchmen, XII, 17) - a utopia. A notable cause, however, it does not stop 
WATCHMEN BY ALAN MOORE AND DAVE GIBBONS:

A PRESENTATION OF MORAL DIMENSION IN POPULAR CULTURE

him from immediately planning his own place and role in this utopia he is to help create as well as making business plans for future investments. He is less of an altruist and more of an "intelligent, opportunistic, individualistic capitalist who plans to benefit financially from his scheme through shrewd investment" (Carney, 2006: para 18). Whereas Veidt so readily recognises the darkness in human heart, he seems to be blissfully oblivious of darkness in his own. Unlike the Comedian and Rorschach who see the world for what it is and formulate their responses accordingly - the Comedian by becoming a parody of a hero, and Rorschach by turning himself into an unrelenting weapon of moral punishment - Veidt is emblematic of the moral hypocrisy these two renounce.

Veidt therefore perceives himself as an agent of good, while his actions suggest otherwise. Inspired by the way Alexander the Great unravelled the Gordian knot, Veidt realises that "an intractable problem can only be resolved by stepping beyond conventional solutions" (Watchmen, XI, 25). The unconventional solution is to trick the countries of the world into cooperation by giving them a common threat against which they could all unite. Unsurprisingly, the logic of Veidt's plan is borrowed from fascist rhetoric: "Hitler said people swallow lies easily, provided they are big enough". (Watchmen, XI, 26). For the good of the world, Veidt sacrifices not only half of New York but also the scientist and artists that helped him create his threatening "alien" life form, and all those in any way connected to his plan. Ends justify the means, acts are to be judged by their welfare outcomes - however, Veidt's take on utilitarianism is too extreme. As Robert Loftis notices, "it certainly looks as if consequentialism contributed to [Veidt's] corruption by allowing him to rationalise self-serving ends and blinding him to the profound injustice of what he has done" (White, 2009: 66). Veidt self-appoints himself to be saviour of the world, the protector of the freedom, but fails to answer who is to protect the world and freedom from a narcissistic megalomaniac such as himself who feels destiny has granted him the moral entitlement to take lives of millions.

In chapter XII Veidt admits that it was not an easy decision to make, that he feels the burden of guilt and how at night dreams plague him of swimming towards a ship. The ship - the Black Freighter - sets sail in chapter III and intersperses the narrative, counterpointing and commenting it, building a sense of foreboding. Tales of the Black Freighter is a comic book read by one of characters and recounts the frantic efforts of a young 
mariner - who finds himself marooned on an island and the sole survivor of an attack by the Black Freighter, a hellish ship manned by damned souls - to return home fearing that his hometown might be the target of the Freighter's next attack. In many ways the story reiterates the gradual process of moral corruption and loss of humanity suffered by Veidt. Both the mariner and Veidt are driven by an "innocent intent" (Watchmen, XI, 13) but their actions become more questionable and contradictory as they progress, and they are both blind to that degradation. The mariner's desire to save his loved ones makes him resort to desperate means to escape the island, such as devising a raft from the swollen corpses of his shipmates, whereas Veidt creates his grotesque alien creature to save mankind. The mariner's journey across the sea leaves him increasingly distraught as the battles both the nature and himself, to the point that he no longer recognises his reflection in the water. Similarly, Veidt becomes his own worst enemy - literally, since he had orchestrated a fake attempt on his own life, but also in the sense that he can no longer recognise his actions for what they are - he dissociates himself from his actions, and becomes unrecognisable to himself. Many other clues resonate through this chapter, the most poignant one being the story of a father driven into murdering his children by fear of nuclear warfare. The end result seems to be the same - an irreversible loss of humanity. As a prose insertion concludes, "though [the mariner] has escaped from his island, [he] is in the end marooned from the rest of humanity in a much more terrible fashion" (Watchmen, V, 61). Veidt, to all intents and purposes, shares the same fate.

As if counterpointing the moral extremes of Veidt, Rorschach, the Comedian, and even Dr Manhattan, Watchmen throws into this morally fractured world a remarkably unremarkable hero, Dan Dreiberg or the second Nite Owl, unremarkable by comparison to other masked heroes previously discussed, except perhaps Hollis Mason. As Mark White notices, Dan Dreiberg is the "everyman" (2009: 79) - though smart and wealthy, both his intelligence and fortune are but a fraction of Veidt's; though he is a good fighter, he lacks the physical prowess of the Comedian or adroitness and agility of Rorschach. He is driven into becoming a masked adventurer by his enthusiasm and want of nothing better to do, as well as his apparent love of owls. When the Keen Act takes effect, Dreiberg retires and dedicates himself to ornithology. "He is an ordinary guy in an extraordinary world, doing good without ruining himself in the process" (White, 2009: 79). As Hollis Mason 
WATCHMEN BY ALAN MOORE AND DAVE GIBBONS:

A PRESENTATION OF MORAL DIMENSION IN POPULAR CULTURE

observes, "part of the art of being a hero is knowing when you don't need to be one anymore" (Watchmen, III, 14), a view that Veidt, but also Rorschach, do not ascribe to. "They impress us with their heroic intentions and devotion but at the same time disturb us with their moral extremism" (White, 2009: 79), whereas Nite Owl seems to strike the balance between the two. Though he is not initially convinced by Rorschach's theories, Dreiberg does break him out from jail when he realises there was some truth to his words, and helps him in his investigation. He calls Veidt's plan madness, but when faced with the fact it had already been executed, decides to keep quiet, not because he justifies it, not because he is concerned with the outcomes if the truth is revealed, but because he believes that such questions are "too big" and that no one human should make such a decision. In the context of the Watchmen universe, it is easy to mistake Dreiberg's moderation for mediocrity. However, his moral stance may be best defined by his views on ornithology - while we are busy "with the sensibilities of statisticians and dissectionists, we distance ourselves increasingly... we forfeit a glimpse of living canvases" (Watchmen, VII, 2). He too understands the darkness of human heart but does not allow it to blind him to mankind's achievements and merits, as well its ability for redemption. Moments before Veidt's alien creature explodes in New York, we see people, complete strangers, jumping in to help break up an increasingly physical quarrel between two lovers, and this gesture seems to give credence to Dreiberg's views.

The heroes of Watchmen fail to stop Veidt, and in doing so "fail to prevent the Earth's salvation" (Watchmen, XII, 2). In a sense, Watchmen's true fearful symmetry is embodied in this "moral checkmate". They can either reveal the truth, crushing the peace obtained at the cost of millions of lives, or they can keep quiet and let the culprit prosper. Everyone agrees that a compromise must be made for the sake of humanity, and that keeping the secret is the best solution. Only Rorschach is unable to compromise since doing so is incongruous with his moral integrity, his adamant refusal to look the other way. As Kant states "it is better to sacrifice life than to forfeit morality. It is not necessary to live, but it is necessary that so long as we live, we do so honourably" (White, 2006: 26). Rorschach's choice is the ultimate expression of his non-consequentialism - he refuses to live as a hypocrite, and therefore has to die a flawed hero.

Although Veidt believes to have created a new world, Rorschach's death strikes an odd cord in more ways than one. It is difficult to imagine that the wider public would have ever supported or heeded Rorschach's 
accusations; therefore his death is rendered futile. On the other hand, if Rorschach's revelations about Veidt's horrid plan came to light, they might not have caused chaos, the much feared nuclear Armageddon, but proved instead to be that one momentous event to shake the world from its moral slumber. However, the protagonists, Rorschach included, preclude such an outcome and simply assume that the worst case scenario is also the likeliest. Watchmen therefore seems to tentatively reaffirm that, given choice, people may still choose not to act morally - a rather grim foreboding for Veidt's precarious utopia. Another question becomes inevitable, whether utopia built on lies is not only acceptable, but sustainable and, more importantly, whether utopia can be achieved at all? The epigraph to chapter XI, which ends in the explosion of Vedit's bomb, quotes Percy Bysshe Shelly poem about the legacy of Rameses II, the greatest and the most powerful of all Egypt's pharaohs: "My name is Ozymandias, king of kings. Look on my works, ye mighty, and despair" (Watchmen, XI, 28). However, in an ironic twist, those words are inscribed on the pedestal of a ruined statue, with nothing remaining of the great pharaoh's great empire save boundless and bare desert. And though Veidt's plan seems to have birthed a better, stronger loving world, there is nothing to suggest it may last. Moore refuses to give a conclusive answer by leaving Watchmen open-ended. Not only is it impossible to tell if the new world will last, seeing that the staff of New Frontiersman have their hands on Rorschach's journal, but because the reader is "left feeling unsure of the morality of superheroes, and whether the good has prevailed" (Strobel, 2008: 8). The clock seen ticking away minute by minute at the beginning of each chapter towards imminent disaster, is set to twelve o'clock (or midnight) and ready to begin a new countdown.

\section{Politics and ideology vs. morality}

The prose insertion at the end of chapter IV, "Dr. Manhattan: Superpowers and the Superpowers by Professor Milton Glass", delves into the issue of political morality, or rather of politics vs. morality, questioning the mandates, permissions, restrictions that states have towards one another. The insertion depicts a world torn asunder by aggressive pursuit of conflicting ideologies. "Never before has man pursued global harmony more vocally while amassing stockpiles of weapons so devastating in their effect... And yet wars continue. Currently, no nation on this planet is not 
WATCHMEN BY ALAN MOORE AND DAVE GIBBONS:

A PRESENTATION OF MORAL DIMENSION IN POPULAR CULTURE

involved in some form or armed struggle, if not against its neighbours then against internal forces" (Watchmen, IV, I). Professor Glass discusses the appearance of Dr. Manhattan and the colossal impact it had on the political balance in the world noticing that, rather than inclining the world towards peace, his existence had instead caused an unprecedented nuclear armaments race between the two superpowers, America and Russia. He notices how the "unquestioned military supremacy had also provided [America] with a certain economic leverage where [it] can dictate the economic policies of the western world and direct them to [its] advantage" (Watchmen, IV, II), as well as the said advantage is obtained at the cost of other countries' interests, most notably the Soviet ones.

The flip side of the ideology that advocates arming yourself with the biggest stick hoping it would serve as a deterrent to those who would bring you harm is immediately shown as it becomes obvious that America's military supremacy has been turned from a deterrent into a means of gaining economic advantage. In simple terms, Watchmen questions the legitimacy of the use of military power, and the legitimacy of the authority given to the state to use such power as a means of defence. It reflects on the tenuous line between defending oneself and attacking others - the extent to which it is permissible for a state to exert military power to protect its citizens and interests before such actions are turned into their own contradiction, and become a means of coercion that infringes upon not only the interests, but unalienable rights of other countries. Professor Glass voices his concerns that the Russians are unlikely to endlessly endure such "indignities" and "humiliation". The choice of words is important as it highlights the imbalance and the moral ambiguity that the use of military power to promote stability and peace entails.

Another side to this discussion also focuses on state intervention against internal threats or those perceived as such. In essence, it refers to the social contract by which the authority to use not only the military power, but law and punishment, is taken from the privileged groups or individuals and given to the state, "a bureaucratic apparatus that is supposed to be neutral, offering equal status to all" (White, 2009: 35). The state enforces the law through repressive forces such as the military, the government, and the police, because its position of impartiality in the social contract gives it the authority to do so. Typically, though acting outside the law, the superheroes in comics are viewed in positive light because their actions counter the injustices of a less-than-competent state apparatus. However, that is not the case in Watchmen where ordinary citizens openly begrudge 
the activities of masked heroes and perceive them as the undermining of authority vested in the state, forcing the government to introduce the Keen Act outlawing vigilante activities. In doing so, the order is restored, the authority to exercise judgement and punishment safely returned in the hands of the state and its law enforcing mechanisms.

The conflict between the superhero and the state law enforcement apparatus in the superhero comics genre is typically based on the existence of elements of corruption - corrupt policemen, corrupt politicians acting in collusion with the criminal elements and the like - which a superhero acts in remedy of. The implication is that in order to restore the system to its function it only needs be purged of those corrupt elements, but the inherent flaws of the system itself are largely ignored. Watchmen takes a different approach. Although the state does outlaw masked vigilantes, those working under its auspices, like the Comedian, are more than welcome. The fact that the state has transferred some of its authority to him does not, however, in any way absolve the Comedian of the individual responsibility for his actions - for example, of the responsibility for the gruesome murder of his pregnant Vietnamese lover. If so, does not the state abuse or at least overreach its authority by allowing such "moral lapses" to go unpunished in exchange for his services in fighting for the country and its "causes"? Does the moral ambiguity, or moral corruption, of those who act in the name of the state, undermine the authority of the state, or the legitimacy of the authority by association? Should the state be held accountable for acts of individuals who act in its name and if not, then why? Should the social contract vesting the state with its authority to enforce law be dissolved if the state abandons impartiality, which is the very premise of it authority, for the sake of convenience? Is the presence of such morally questionable elements what leaves the system open to abuse, or is an inherent flaw in the system that allows the presence of such elements in the first place? The Comedian may have returned from the Vietnam as a war hero, but on the other hand, he might have had a hand in the assassination of Kennedy - his actions therefore disrupting the democratic process which he is supposed to protect and uphold. The choice of Richard Nixon, the corrupt president, as the first man of the state in Watchmen is a statement in itself. The Comedian, Nixon, even Dr. Manhattan to an extent - are they the disease or merely a symptom of a far more serious condition? How far should the state be allowed to go, which means are acceptable for the state to use for the benefit of citizens? 
WATCHMEN BY ALAN MOORE AND DAVE GIBBONS:

A PRESENTATION OF MORAL DIMENSION IN POPULAR CULTURE

These questions are revisited in Watchmen through juxtaposition of similar, yet different situations regarding USA war efforts. America wins war in Vietnam by sending Dr. Manhattan, a living H-bomb, a god-like entity, to fight for them. In doing so, countless lives are saved. Dr. Manhattan's involvement beckons another similar instance in history, when actual warheads were thrown on Hiroshima and Nagasaki, killing civilians, but putting an abrupt end to a war that surely would have claimed many more lives. Against those uses of violence that may be perceived as justifiable, Watchmen pits Vedit's exploding "alien" that kills three million people in New York, but turns the world from the brink of nuclear annihilation. Behind all three instances is the utilitarian sacrifice of the few for the sake of the many. What makes these situations different; are they at all different? What are the moral grounds upon which a state decides a war is morally justified? Are thermo-nuclear detonations and ensuing radioactive fallout acceptable means for achieving peaceful ends since they so blatantly undermine the notions of proportionality and reciprocity in warfare by targeting civilians? Is the fact that individuals have ceded both the authority and responsibility for such actions to the state the reason Veidt's is the greater sin? On the other hand, Veidt might reasonably argue that by abandoning diplomatic tools at their disposal in favour of violence, the states have broken social contract, abused the authority and acted against the welfare of their citizens by engaging in war, not against each other, but against whole humanity, and in doing so forfeited any claim to such authority.

Rather than amounting to yet another illustration of the conflict between moral consequentialism and moral non-consequentialism, albeit in a political context - with the former focusing on the end, rather than the means, and latter on the properties of actions rather than their effect - Watchmen instead considers the varying views in themselves as a means of rationalising the abuse of authority and political power. Underlining such considerations is yet another question, and not an altogether surprising one considering that its author quite openly declares himself an anarchist, if the state should ever be given such authority in the first place? Watchmen deliberately refuses to provide a definitive answer to these many questions, becoming instead a medium of reassessment, rather than an opinion poll. It does however, reiterate the need for vigilance, the necessity of watching the watchmen, by suggesting that as long as there is an organised bureaucratic system called the state, the least we can do is remain watchful of its intents and actions. 
Leftist or rightist political views are similarly presented as the means by which the (ab)use of power may be given credence to. On one hand, Rorschach, the deontologist who advocates doing what is right for the sake of doing what is right, also stands for the rightist, radical political views, and Ozymandias, the extreme utilitarian, is described as the most consistently leftleaning superhero. The same applies to two newspapers featured in the narrative, New Frontiersman and Nova Express. New Frontiersman, favoured by Rorschach, endorses the ideology of the far right, even equating the activities of the Ku Klux Klan, and the retaliatory bombing of Beirut in 1979, with the efforts of the Boston Tea Party men and the spirit of the frontiersmen, arguing that sometimes international laws governing the mandate and conduct of states may become inapplicable "through unforeseen circumstances" and asks if "is it not more noble to follow the course of right and justice, to serve the spirit of the law rather than its every dot and comma?" (Watchmen, VIII, 2) - arguing, in effect, in favour of abandoning fundamental principles of human rights. On the other hand, New Frontiersman does perceive the political conflict escalating towards open nuclear confrontation, and does warn of the disappearances of scientists and artists that are later revealed to be integral to Veidt's plans, but these messages are rendered unclear by the inflammatory rhetoric. Nova Express, the voice of the left, viewed as the source of serious journalism, in its quest for truth and the effort to give voice to the little people, falsely accuses Dr. Manhattan of giving cancer to his co-workers causing his exile to Mars, which then destabilises the political situation in the world. Furthermore, it is revealed that Nova Express was but a tool in the hands of Ozymadians, the fact that not only severely undermines its journalistic credibility, but also the credibility of the ideology it endorses. As Robert Loftis notices, "Moore and Gibbons aren't interested in whether the views can be tinkered with to the point they are a reasonable guide to behaviour, because that is not how these ideologies function in the world" (White, 2009: 76). The real question, regardless of the ideology, is still that of power and the moral implication that the use of power entails.

\section{Magical science}

Science and scientist appeared fairly early in comics, with scientific concepts being introduced freely into the plot. However, the use of "science" in comics is superficial at best, and many times it comfortably coexists with 
WATCHMEN BY ALAN MOORE AND DAVE GIBBONS:

A PRESENTATION OF MORAL DIMENSION IN POPULAR CULTURE

magic or is treated as "a special form of magic... mystical, rather than rational" (Reynolds, 1992: 16). Watchmen, yet again, marks a departure from the tradition. Not only is science presented more credibly, but it is completely fused with the narrative in that it represents one of its key elements.

Addressing the perception of perception of science in our culture, John Fiske notices:

We are a science-based culture. The dominant myth of science presents it as [...] the ultimate problem solver, [the token of] the human ability to understand and dominate nature. [Science] increases our material prosperity and security, and it represents one of the pinnacles of human achievement. Science is seen as objective, true, and good [...]. Its connotations are, therefore, of positive moral and functional values: it is good and useful. But the counter myth is also very strong. This sees science as evil, as evidence of our distance from and lack of understanding of nature. As scientists, we are at our most selfish and short-sighted, in pursuit of our own material ends. It is interesting to note that in popular culture both myths of science are well represented. (Fiske, 1990b: 90-91, 170)

In Watchmen, both sides to the argument are equally well-represented. Science and scientific achievements, accelerated by Dr. Manhattan's insight into the inner workings of nature, help improve life around the globe and open new fields of scientific research - the most notable achievements being electric cars and airships. On the other hand, those same achievements and technologies are what enable Veidt to create a believable "alien" creature that kills millions of New Yorkers. Veidt's alien creature, much like his pet Bubastis, is a successful product of eugenics, but it explodes upon teleportation indicating the failure of scientist to fully grasp the fundaments of the process. Watchmen seems to point out both the dangers inherent to tinkering with the unknown, as well as those posed by the abuse of notions and concepts we believe to have mastered through our science.

In many ways this is reminiscent of the atomic bomb, hovering not so silently at the back of the narrative. Harnessing the power of the atom was supposed to bring many benefits to mankind, which it arguably did, but it also enabled the creation of the most devastating weapon in mankind's history, or as aptly stated in the comic book: "we have long laboured to build a heaven, only to find it populated with horrors" (Watchmen, IV, 
I). The argument is a well-known one: science itself is neither good nor bad, it has no intrinsic moral value, but rather, such value is drawn from its function and purpose both of which are ultimately the responsibility of man, reiterating Einstein's famous quote: "The release of the atom power has changed everything except out way of thinking... The solution of this problem lies in the heart of the mankind. If only I had known, I should have become a watchmaker" (Watchmen, IV, 28).

This, in turn, begs another question: if the use (or abuse) of science depends on our moral principles, how does scientific progress affect our moral selves? Should scientific progress and ethics come hand in hand? Do our moral convictions hamper scientific progress? During one of their earlier encounters, Adrian Veidt gushes about the great leaps in science achieved because of Dr Manhattan's involvement. "With your help", says Veidt, "our scientists are limited only by their imaginations", to which Dr Manhattan replies: "And by their consciences, surely" (Watchmen, IV, 21).

Dr Manhattan is the embodiment of the scientific progress that mankind's conscience is not prepared for, that tests our moral sense. He is quite literally shaped by science that exceeds human knowledge, and more importantly, the existing ethical structures do not accommodate his existence. Hence the "feeling of intense and crushing religious terror" (Watchmen, IV, II) that sweeps the planet once he is revealed to the world, a sentiment echoing each major scientific breakthrough ever achieved. If our everyday lives evolve with the help of science, should not our moral selves evolve as well? Dr. Manhattan leaves the Earth and its many moral quandaries seeking a simpler world where he would be able to attempt the thermodynamic miracle of creating life. Though he himself has "evolved", the world is unable to keep up with this evolution suggesting a need for at least a revaluation, if not a whole new set of values that would allow further progress. Ultimately, what Watchmen offers is not a request for revaluation of moral values and principles that affect our perception of science and scientific progress, as much as a warning, yet again, against a system of values that has become ossified and impervious to change.

\section{Conclusion}

Any discussion regarding Watchmen inevitably leads to the question of both its relevance and status as "literature". Though the issue was 
WATCHMEN BY ALAN MOORE AND DAVE GIBBONS:

A PRESENTATION OF MORAL DIMENSION IN POPULAR CULTURE

touched upon, the aim of this paper is not to establish or deny the literary relevance of Watchmen in particular, or the comics medium in general. Rather, the paper acknowledges the comics to be a "hybrid art form that comes from the interbreeding of two or more different kinds of art forms, technologies, genres, or artistic media" (Meskin, 2009: 168) and that it is not necessary to show that it is literature in order to establish its worth as a vehicle for producing meaningful reading(s).

On another note, it might better serve the purpose of this paper to reflect on its role and relevancy as a product of popular culture. In his book Understanding Popular Culture, John Fiske wrote that "popular culture must not preach". He also added that "the problem with some forms of realism is that they attempt to provide an answer for, or a 'true' insight into, the problems of industrial society", noting that "however politically correct this might be it denies the productivity of popular culture; it minimizes the producer elements in the text, or, at least, attempts to close them down". Fiske goes on to conclude that products of popular culture "do not propose a 'party line' of socially correct meanings, but offer contradictory and controversial representations, and thus allow for producerly readings" (2010: 145). In her article "Why popular culture matters", Marcelline Block answers the question by asserting that "in reflecting, expressing, and validating the spirit of our epoch - the zeitgeist - [popular culture] generates meaning, and not only interacts with and situates the current state of our society but also helps and shape and inform its future" (2012: 15). Watchmen reflects both views - it does capture the spirit of an epoch but in a way that makes it invested in the future, and it most certainly does not preach; in fact it quite openly invites readers to formulate their own interpretations and readings. However, it may be argued that Watchmen's greatest claim to relevancy is its continued ability to produce new readings, even those, as Ian Thompson notices "which radically reorient our original sense of the work" (2005: 104).

This paper offers one such re-reading. Its aim is to shed light on the presentation of the moral dimension in Watchmen by considering varying philosophical views, most notably that of moral consequentialism and moral non-consequentialism. In Watchmen, these varying views are examined through a series of questions regarding the ethical principles of authority, responsibility and moral judgement and how they inform moral convictions and moral choices of individual characters, but also in terms 
of how they inform our politics, ideology, and science. Rather than being a critique or affirmation of any view, Watchmen considers them as a means of rationalising the use and abuse of power. Moore refuses to make judgements about the actions of the protagonists or about the world at large and this ambivalence is indicative of his desire for the audience to engage the issue themselves. On a different note, what More does offer is a tentative warning about the dangers inherent to the ossification of value systems and proposes that a way to counter this apparently inevitable process, is to remain vigilant, to watch over oneself as much as others. Ultimately, since it is the readers' world and the readers have to make their own choices, Watchmen and Alan Moore leave it "up to [the readers] to formulate their own response... and not be told what to do by a superhero, or a political leader or a comic book writer for that matter" (Khoury, 2009: 114).

\section{References}

Block, M. (2012). Why Popular Culture Matters, Popular Culture, 2012 Issue, Bristol: Intellect.

Carney, S. (2006). The Tides of History: Alan Moore's Historiographic Vision. Image TexT: Interdisciplinary Comics Studies, Volume 2, Issue 2 [on-line] Avaliable: http://www.english.ufl.edu/imagetext/archives/v2_2/carney [26.3.2014].

DeScioli, P. and Kurzban, R. (2008). "Cracking the Superhero's Moral Code.”Ed. Robin Rosenberg. The Psychology of Superheroes: An Unauthorized Exploration. New York: Ben Bella, p. 245-258.

DeScioli, P. And Kurzban, R. (2009). Mysteries of morality. Cognition, Elsevier. doi:10.1016/j.cognition.2009.05.008, p. 281-299.

Di Liddo, A. (2009). Alan Moore: Comics as Performance, Fiction as Scalpel. Jackson: University of Mississippi.

Effron, S. (1996). Taking Off the Mask: Invocation and Formal Presentation of the Superhero Comic in Moore and Gibbons' Watchmen. (unpublished thesis). Wesleyan University, Middletown.

Fiske, J. (1990a). Understanding Popular Culture. London and New York: Routledge.

Fiske, J. (1990b). Introduction to Communication Studies. London and New York: Routledge.

Fishbaugh, B. (1998). Moore and Gibbon's Watchmen: Exact Personifications of Science. Extrapolation. Volume 39, No. 3. The Kent University Press.

Flynn, T. (2012). Discovering the Literary Relevancy of Watchmen: A Review of the Graphic Novel's Philosophical Themes. Liberty University. 
WATCHMEN BY ALAN MOORE AND DAVE GIBBONS:

A PRESENTATION OF MORAL DIMENSION IN POPULAR CULTURE

[online]. Available: http://digitalcommons.liberty.edu/cgi/viewcontent. cgi? article $=1282$ \& context=honors [05.04.2014].

Hughes, J. (2006). "Who Watches the Watchmen?": Ideology and "Real World"

Superheroes. The Journal of Popular Culture, Volume 39, No 4. Blackwell Publishing Inc.

Khoury, G. (2003). The Extraordinary works of Alan Moore. Raleigh: Two Morrows. McCloud, S. (1994). Understanding Comics. New York: Harper Collins Publishers Inc. Narcissi, L. (2013). The Apocalypse is Here, Again: Moral Ambiguities and Human Failings in Watchmen. [on-line] Available: https://www.inter-disciplinary.net/critical-issues/wp-content/uploads/2013/05/narcisiapopaper. pdf [26.3.2014].

Rapp, E. (2012). Watchmen: Deconstructing the Superhero. North Dakota State University Libraries. [online] Available: http://ibrary.ndsu.edu/tools/ dspace/load/?file=/repository/bitstream/handle/10365/22356/Watchmen. pdf?sequence $=1$ [05.04.2014.].

Reynolds, R. (1992). Superheroes: A Modern Mythology. London: Batsford.

Suvin, D. (1979). Metamorposes of Science Fiction. On the Poetics and History of a Literary Genre. New Haven \& London: Yale University Press.

Thompson, I. (2005). Deconstructing the Hero. In McLaughlin, J. ed. Comics as philosophy. Jackson: University Press of Mississippi.

Varnum, R. and Gibbons, C.T. (2001). The Language of Comics: Word and Image. Jackson: University Press of Mississippi.

White, M. ed. (2009). Watchmen and Philosophy: A Rorschach Test. Hoboken, New Jersey: John Wiley \& Sons, Inc.

\section{Sources}

Moore, A. and Gibbons, D. (1987). Watchmen. New York: DC Comics.

Moore, A. (2003). Alan Moore's Writing for Comics. Urbana, IL: Avatar Press.

Moore, A. (2000a). "Blather: The Alan Moore Interview." Blather. [on-line] Available: http://www.blather.net/articles/amoore/index.html [26.05.2015]

Moore, A. (2000b). "Toasting Absent Heroes: Interview with Alan Moore". Comics Book Artist 9. [online] Available: http://www.twomorrows.com/ comicbookartist/articles/09moore.html [26.05.2015]. 
Gordana Bogićević

\section{Rezime}

\section{WATCHMEN ALAN MOORE-A I DAVE GIBBONS-A: PREDSTAVLJA- NJE MORALNE DIMENZIJE U POPULARNOJ KULTURI}

Grafička novela Nadzirači autora Alana Mura i ilustratora Dejva Gibonsa ispituje moralnu dimenziju u domenu popularne kulture nudeći uvid u različite filozofske pozicije, pre svega moralnog konsekvencijalizma i deontologije, pri čemu se ova viđenja razmatraju kroz niz pitanja o etičkim principima autoriteta, odgovornosti, i moralnog produđivanja kako i kakav uticaj oni imaju na moralna ubeđenja i izbore pojedinaca, ali i kakvu ulogu imaju u širem društvenom kontekstu, pre svega u domenu politike, ideologije i nauke. U žiži interesovanja je povratna sprega procesa obrazovanja i razvoja moralnih ubeđenja i njihovih ishoda, i njihov uticaj na društvo. Nadzirači ne nude ni kritiku ni afirmaciju bilo koje pozicije, već ih posmatraju kao načine na koji se opravdava (zlo)upotreba autoriteta i moći. Rad pokazuje kako odbijanje da se prikloni bilo kojoj poziciji zapravo ukazuje na želju autora Alana Mura da čitaoci samostalno preispitaju stavove o moralnosti, uz implicitno upozorenje o opasnosti okoštavanja svakog sistema vrednosti.

Ključne reči: popularna kultura, stripovi, Watchmen, moralni konsekvencijalizam, odgovornost, politika i ideologija, nauka 